\title{
INTERNATIONAL ASSOCIATION FOR HYDRAULIC RESEARCH
}

\section{COMMITTEE ON HYDRAULIC LABORATORY INSTRUMENTATION}

During the International Congress of IAHR in Baden-Baden, a committee of Hydraulic Laboratory Instrumentation was established within Division II Experimental and Mathematical Fluid Mechanics - Section on Fundamentals.

The committee was formed to advance the knowledge of laboratory instrumentation and also to promote new developments and the usage of available instruments. Work on new methods to measure fluid mechanics properties will be stimulated by the committee and assistance will be provided to people interested in applying advanced laboratory instrumentation.

Committee members were selected from people who are experts in the field of laboratory instrumentation in general and have special knowledge in the various fields in which hydraulic laboratory instrumentation are needed to carry out experimental work. Committee members were selected from different countries to have a proper geographical representation in the committee. The present members are:

$\begin{array}{ll}\text { Professor Dr. F. Durst (Chairman) } & \text { Dr. W. Majewski (Co-Chairman) } \\ \text { Institut für Hydromechanik } & \text { Polish Academy of Sciences } \\ \text { Abteilung III } & \text { Institute of Hydroengineering } \\ \text { Universität Karlsruhe } & \text { Cystersow 11 } \\ \text { Kaiserstraße 12 } & \text { GDANSK - 5 } \\ \text { D-7500 KARLSRUHE, FRG } & \text { Poland } \\ \text { Dr. L. Dolezel } & \text { Dr. A. C. M. van Ette } \\ \text { Water Research Institute } & \text { Delft Hydraulic Laboratory } \\ \text { Podbabská 30 } & \text { Van Kinschotstraat 17 } \\ \text { 16000 PRAHA 6 } & \text { DELFT } \\ \text { CS S R } & \text { Netherlands } \\ \text { Dr. A. Müller } & \text { Dr. J. M. Delhaye } \\ \text { Institut für Hydromechanik \& } & \text { Centre d'Etudes Nucleaires de Grenoble } \\ \text { Wasserwirtschaft } & \text { Service Transferts Thermiques } \\ \text { ETH Zürich } & \text { Boite Postale 85, centre de tri } \\ \text { ETH-Hönggerberg } & \text { 38041 GRENOBLE Cédex } \\ \text { 8093 ZÜRICH } & \text { France }\end{array}$

Switzerland

The committee is presently preparing a detailed questionnaire which will be sent to different laboratories in which instruments are employed to carry out velocity measurements in singleand two-phase flows. The work going on in the different laboratories will be documented and will be available in the form of a report. This report will also provide an introduction into those velocity measuring techniques that are most suitable for experimental studies. The committee is presently aiming to have a colloquium on new developments in laser-Doppler anemometry in Karlsruhe in 1980 and to have a seminar on new developments in hydraulic laboratory instrumentation during the IAHR-Congress in 1981. 